\title{
An information literacy tutorial for the Valencian educational context (Spain)
}

\author{
Rosa Maria Guerrero-Vives \\ University of Balearic Islands (UIB) \\ Carretera de Valldemossa, Km 7,5. Palma (07122) \\ Spain \\ rosamaria.guerrero@uib.cat \\ Maria Dolores Rubio-Mifsud \\ Institute of Valencian Librarians and Documentalists (COBDCV) \\ Polytechnic University of Valencia. Camí de Vera s/n. 1H Building. València (46022) \\ Spain \\ madorumi@gmail.com \\ Mercè Morey-López \\ University of Balearic Islands (UIB) \\ Carretera de Valldemossa, Km 7,5. Palma (07122) \\ Spain \\ merce.morey@uib.cat
}

\begin{abstract}
This paper presents an IL tutorial developed by the School Libraries Working Group from the Institute of Valencian Librarians and Documentalists and the Research Group on Education and Citizenship from the University of Balearic Islands (Spain). Firstly, a description of the information literacy training in Spanish educational centers is given. Secondly, the contents of the tutorial are explained. This tutorial has been developed by following the Three-Phase Model (Blasco and Durban, 2011), a model scientifically acknowledged and widely used in the Spanish context. Moreover, recommendations from educational researches and other IL tutorials are considered as well. Finally, an assessment tool is presented with the aim of improving this instrument and to adapt it to the real needs of teachers and students. The first assessment of this tutorial will be developed during the Doctoral Forum that will be celebrated on June-July 2015 in Maastricht.
\end{abstract}

Keywords: Information Literacy, Secondary Education, Teacher Education, Information Literacy Tutorials, Critical Thinking, Secondary Education Students, València (Spain), Spain.

\section{Introduction}

This document sets out the chosen procedure for the development of an information literacy tutorial in the Valencian (Spain) secondary education context. Given the Valencian outlook, and the Spanish one in general, the need to take action is clear, not only for the management of the school library as a service to the non-university educational community, 
but also to promote the autonomous and free learning and to improve teachers education in this field.

We consider this tool will also be an interesting resource from which teachers -who generally feel unfamiliar with these skills (Probert, 2009)- will learn more about this learning resource and will appreciate its usefulness in promoting research in their classrooms.

\section{An outlook of the school libraries situation and information literacy treatment in Spain. The Valencian case}

In less than forty years of political democracy, the Spanish educational system has been modified seven times. This fact has affected their management in general, as well as to their school libraries development (Gómez-Hernández, 2002).

The 113th article of the LOE (Organic Law for Education) (Order 2/2006) mentioned for the first time the school library and it stated the obligation of the educational center to have a place wherein to encourage reading promotion, access to information and to analyze data critically. This premise has remained in the current LOMQE (Organic Law for the Improvement in the Quality Education) (Order 8/2013), although with slight modifications that make the need to regulate the school librarian professional role clear. This role has been recently recognized in the list of profiles of the Spanish Library System (Tejada-Artigas, Martinez-Gonzalez, Rodriguez-Bustamante, Cid-Rodriguez Comalat-Navarro, et al., 2013), to ensure lifelong learning in the information age.

According to Jiménez-Fernández and Cremades-Garcia (2014), there is still a long way to go in terms of management and promotion of the school library in Spain. Firstly, there are no teachers-librarians work in the school library during the entire workday. Secondly -and paying attention to the IL promotion- teachers do not have time to teach it (as an extra-academic knowledge) because of the sheer size of the everyday curricula. In addition to this, it has been recently shown that teachers IL skills are inadequate to the teaching task.

Beyond the limits of the Public Educational context, we have to point out determinant actions like those developed by Germán Sánchez Ruipérez Foundation (FGSR), an institution focused on cultural and educational activities promotion. Thanks to this, a self-assessment tool for school libraries (Miret, Baró, Mañá, Vellosillo and Montero, 2010) and also a State Directory of School Libraries (FGSR, 2015) have been created. Certainly, we deal with fundamental actions that eventually will enhance the quality of library services at school centers and will be strengthened by individual actions undertaken by each of the autonomous governments in recent years.

There exists some examples of IL actions developed in the different autonomous communities such as: the collection of experiences and resources for the informational competences in the Murcia, Extremadura and Andalusia classrooms; studies on plagiarism (Comas-Forgas, Sureda-Negre, Angulo-Rasco and Mut-Amengual, 2011) and studies on informational literacy (Morey-López, Sureda-Negre, Comas-Forgas and Mut-Amengual, 2010) of the students from the Balearic Islands, and finally, the development of the ThreePhases Model (Blasco and Durban, 2011) in the context of the Catalan primary and secondary education. This last action has been taken as a reference for other reading and IL projects such as those of Andalusia, Astúries and Galicia. 
Apart from a noticeable deficit on the educational legislation regarding IL promotion in nonuniversity education, another factor that has influence negative in its promotion has been the ineffective teacher education programs in this field. According to Álvarez-Herrero, teachers have a distorted image of this kind of learning: "It is unfortunate that secondary education teachers tend to consider ICT have time-saving aids in their classes instead of considering their value in terms of professional development" $(2015,135)$. This idea is further supported by other studies which state that teachers themselves are unaware of the full value of the IL concept (Probert, Op. cit.; Guerrero-Vives, 2012).

The results of IL levels (Álvarez-Herrero, Op. cit.) make it clear that Spanish teachers even if they are able to identify an information need and use certain resources in order to locate it, they do not know how to evaluate nor organize information neither how to transform it into knowledge nor how to communicate it. This setback increases when we speak about the teaching professionals at the communities of Castile and León, Balearic Islands, Valencia and Navarre, where the conclusion is that "there is something wrong in these regions in terms of informational literacy" (Álvarez Herrero, Op. Cit., 140) and it indicates a need for a renovation of the teacher training plans in order to improve this learning.

Leaving a sight the problems of IL in the educational world we should point out that Spanish Public Libraries are working hard to meet the individual IL needs of each users profiles (Castillo-Fernández, Gómez-Hernández, Quílez-Simón, 2010). In the case of young users, they try to develop activities through which they become familiar with information resources and information processing (Generalitat de Catalunya, 2015). Little wonder then, that among the priorities of work in libraries, especially those in higher-education institutions, we find IL projects based on independent learning, documentary research and plagiarism escape.

Undoubtedly, teachers IL levels are alarming. There is no question but that it is essential to develop a training tool to which help teachers to embrace these skills and try to transmit these to their students.

\section{Current Valencian situation}

Despite the efforts of the Valencian autonomous administration during previous years with school libraries management software tool 'PMB', educational centers do not have the human and resources to start using it. Additionally, there is no Valencian school library network sufficiently established that allows the exchange of resources and teaching experiences. This situation highlights the difficulties of a hypothetical IL program school libraries because unfortunately neither libraries nor the teaching staff are provided with sufficient resources to teach the subject.

Being aware of the situation in this area, the Institute of Valencian Librarians and Documentalists (COBDCV), represented at the Valencian Libraries Advisor Council (Decree 4/2011), is conducting some training activities with the objective of introducing IL among the Valencian teaching staff. With this action it is intended to familiarize the course participants with this learning and to collect their perceptions about the quality of the research papers presented by their own students, in order to identify those elements requiring improvements. According to this second purpose, we can say that the research projects presented tend 
towards the same discount reflected in similar studies (Merchant and Hepworth, 2002; Williams and Rowlands, 2007; Guerrero-Vives, Op. cit.).

In the Valencian secondary education curricula degree (Decree 112/2007), at the fourth course of the Compulsory Secondary Education (ESO) we find the optional subject 'Research Project'. This research project is an individual choice guided by the teacher.

This work is represented through an online tutorial that will help, firstly, to internalize the knowledge related to this learning for teachers, and secondly, to help as a work model for students who wish to do serious academic research projects. It is the intention of this working group to try to standardize the proposed tool so that it can be adapted to other social and cultural environments.

In the following section we will explain the process of the development of this tool and we will consider the fundamental elements required for this properly evaluation.

\section{Description of the production of an online IL tutorial for secondary education}

In this section are described, firstly, the structure and contents of the online tutorial and secondly, the main elements which will be considered for the tutorial experts' validation.

\section{Online Tutorial}

According to the Valencian secondary education legislation (Op. Cit.), students of fourth Compulsory Secondary Education course, are required to allocate an hour per week to the Research Project subject. The proposal is that the IL tutorial could be utilized in a step by step fashion over the course of the school year to assist in the production of each individual's research project. Besides explaining the main IL tasks, the examples given in this paper are related to the same subject: Les Germanies.

At the next step, the Three-Phase Model taken as our model basis, the online tutorial contents and its technical features are described.

\section{The Model}

The Three-Phase Model (Blasco and Durban, Op. cit.) was developed according to the Catalan legal framework, but nowadays is widely used in the whole Spanish context. At the website Biblioteca escolar: experiències i recursos per a la competència informacional (Bibliomèdia, 2015) there are many educational sources based on this model.

According to Blasco and Durban, the importance of comprehensive in depth reading is rightly underscored in their model. Such reading being vital in knowledge location, retrieval and retention.

Although there are not much differences between other IL theoretical frameworks developed (Gómez-Hernández and Pasadas-Ureña, 2007), the main aspects of the Three-Phase Model are exposed: 


\begin{tabular}{|c|c|c|}
\hline \multicolumn{3}{|c|}{ Three-Phase Model } \\
\hline \multirow[t]{3}{*}{$\begin{array}{l}1 . \\
\text { Informa } \\
\text { tion } \\
\text { Retriev } \\
\text { e }\end{array}$} & Planning & $\begin{array}{l}\text { Identify information needed } \\
\text { Set features } \\
\text { Organize a work project }\end{array}$ \\
\hline & Searching & $\begin{array}{l}\text { Know specific sources } \\
\text { Outline searching strategies } \\
\text { Search and locate sources }\end{array}$ \\
\hline & Retrieving & $\begin{array}{l}\text { Evaluate results } \\
\text { Select the best sources } \\
\text { Get information }\end{array}$ \\
\hline \multirow{2}{*}{$\begin{array}{l}2 . \\
\text { Informa } \\
\text { tion } \\
\text { Proces } \\
\text { s }\end{array}$} & Reading & $\begin{array}{l}\text { Understand the information } \\
\text { Read critically }\end{array}$ \\
\hline & Synthesizing & $\begin{array}{l}\text { Extract relevant information } \\
\text { Organize the extracted information }\end{array}$ \\
\hline \multirow[t]{3}{*}{$\begin{array}{l}3 . \\
\text { Comm } \\
\text { unicate }\end{array}$} & Generating knowledge & $\begin{array}{l}\text { Integrate new information } \\
\text { Incorporate personal experiences } \\
\text { Behave ethically and responsibly }\end{array}$ \\
\hline & Knowledge communicating & $\begin{array}{l}\text { Prepare the final product } \\
\text { Share the acquired knowledge }\end{array}$ \\
\hline & Evaluation and application of the know-how & $\begin{array}{l}\text { Judge the product and the process } \\
\text { Transfer the acquired knowledge to others }\end{array}$ \\
\hline
\end{tabular}

Table 1. Three-Phase Model translated from Blasco and Durban (Op. cit.).

In this figure one can see that this model underlines the reading and synthesizing actions with the aim to develop a comprehensive reading. Also, the evaluation of the entire process is another interesting action which helps students to assimilate and think about information management and use in all life contexts.

Tutorial Contents

Knowing how difficult it is to transmit reading skills to students and the negative points detected in online IL tutorials (Michel, 2001; cited in Lindsay, Cummings, Johnson and Scales, 2006), the contents and the technical features of our tutorial are explained.

\section{The Subject Research}

With the aim of explaining as well as possible the IL contents, it was thought relevant to establish a one only subject and expound on it over all the IL tutorial stages. 
The online tutorial is located in the website www.alfinsecundaria.zyro.com. The research samples given are connected with each general section (Search, Process and Communicate) and are focused of the subject of Les Germanies. This subject is included in the Valencian curricula of History (fourth course of Compulsory Secondary Education).

The historical episode of Les Germanies was an uprising which occurred between 1519 and 1523 by artisans guilds and farmers from different Valencian areas. The reason noted that in a few years the $500^{\text {th }}$ anniversary of this event will be celebrated. And, in addition, the number of educational sources related with this item will presumably increase. Moreover, the information related with this item could be retrieved not only from libraries or information centers but also from local and historical archives. In this field, the possibilities of retrieving different kind of documents would be increased too. Finally, the retrievable sources were analyzed with the aim of checking that the contents were according to the comprehension level of secondary education students.

\section{The fictionalized contents}

To accord with the IL experiences in the use of graphic novels (Hoover, 2012; Upson and Hall, 2013), fictionalized contents in this tutorial are considered too. The reason why we include this kind of contents is because we thought it would be interesting to empathize students and teachers with the protagonist of a graphic novel: a fifteen year old teenager who needs to prepare a research project about Les Germanies. This young boy will face typical IL stressing situations such as procrastination, information anxiety or plagiarism temptation.

\section{Technical elements}

The tutorial was developed in the www.zyro.com platform, a quite intuitive website builder which does not require a high level of HTML or PHP language knowledges. Inside of this structure we can find other technical elements as follows:

- Explanatory videos on the use of online documentary resources, such as the Online Public Access Catalogue of the Valencian Public Libraries Network.

- Serious but simple games. Even the platform limitations where the tutorial is hosted, and being aware of the positive contribution of serious games to the library context (Markey, Leeder \& Rieh, 2014), the tutorial includes easy and ludic activities.

- Internal links, that will take us to certain tutorial places such as the glossary.

- External links to other websites.

- Tutorial Guide for Teachers.

- Pre-test and post-test evaluations for each IL phases.

\section{The evaluation tool}

The technical evaluation tool of the tutorial will be done according to the recommendations of Somoza-Fernández and Abadal (2009). The indication of Information Literacy will be taken into account following the instructions proposed at the Three-Phases Model. Moreover, the evaluation will include a textual content analysis, with the objective of discovering whether these are sufficiently adapted for the level of students of the fourth course of the Compulsory Secondary Education. Data will be collected by a Likert Scale and some qualitative questions. However, these contents are not definitive yet. 


\section{Conclusions}

Information Literacy is a learning process that has not yet arrived in classrooms as itself. Educational centers have not yet allocated spaces, human resources or materials to exploit this valuable resource efficiently. The tutorial presented in this conference has been created with the objective to promote a potential answer to this obvious gap in the Education System with particular reference to the Valencian region.

Bearing in mind the kind of user for whom this tool is designed, it is considered essential to include dynamic elements and graphics that really attract and stimulate young people to learn more about information management and, needless to say, to apply critical thinking on what they read.

We think that this tool is an interesting way to introduce IL at secondary school, even though it is not fully comprehensive for all levels.

The Information Society to which young people adapt so easily need to carry out more solid action not only by schools but also by families (Marquina, 2013). The present digital divide could become even larger developing into a second digital divide (Busquet and Uribe, 2011). Any limitations in the use or access to information in the information age can have a negative impact on future employment prospects (Ruiz Antón, cited on Pérez de Pablos, 2015).

Note: contents have been developed using the www.stripgenerator.com comic tool

\section{References}

Álvarez-Herrero, J. A. (2015). La alfabetización informacional del profesorado de educación secundaria del estado español (Doctoral thesis published DL: T-273-2015). Universitat Rovira i Virgili, Catalunya, Spain. Retrieved from: http://www.tdx.cat/bitstream/handle/10803/285937/Tesi\%20Juan\%20F\%20Alvarez \%20herrero.pdf

Benito Morales, F. (1995). Del dominio de la información a la mejora de la inteligencia: diseño, aplicación y evaluación del programa Hebori (Habilidades y estrategias para buscar, organizar y razonar con la información) (Non-published thesis). Universidad de Murcia, Spain.

Bibliomèdia. (2015, March, 20). Biblioteca escolar: experiències i recursos per a la competència informacional. Retrieved from: https://sites.google.com/a/xtec.cat/cinfoa-bbm/

Blasco, A. \& Durban, G. (2011). Competència informacional: del currículum a l'aula. Barcelona: Associació de Mestres Rosa Sensat.

Busquet, J. \& Uribe, A. C. (2011). Proyecto AUSTICA. El uso de las TICs y la Brecha Digital entre adultos y adolescentes. Primer avance de resultados. In Escuela Universitaria de Magisterio de Segovia (Ed.), Congreso de Educación Mediática y Competencia Digital. Segovia (Spain), October, 13-15. 
Castillo-Fernández, J.; Gómez-Hernández, J. A. \& Quílez Simón, P (Eds.). (2010). La biblioteca pública frente a la recesión: acción social y educativa. Murcia: Tres Fronteras, ANABAD.

Comas-Forgas, R., Sureda-Negre, J., Angulo-Rasco, F. \& Mut-Amengual, T. (2011). Academic Plagiarism amongst Secondary Education Students: State of the Art. 4th International Conference of Education, Research and Innovations Proceedings, 4314-4321. Madrid: IATED.

Decree 112/2007, Valencian Secondary Education Curricula. Diari Oficial de la Generalitat Valenciana, 5562. Retrieved from: http://www.docv.gva.es/datos/2007/07/24/pdf/2007 9717.pdf

Decree 4/2011, Valencian Libraries Management. Diari Oficial de la Generalitat Valenciana, 6488. Retrieved from: http://www.docv.gva.es/datos/2011/03/25/pdf/2011 3381.pdf

Fundación Germán Sánchez Ruipérez (2015, March, 20). Directorio Estatal de Bibliotecas Escolares. Retrieved from: http://62.174.65.116/wbibes/

Generalitat de Catalunya. Departament d'Educació (2015, March, 20). La biblioteca. Retrieved from: http://www.edu365.cat/vadellibres/biblioteca/index.html

Gómez-Hernández, J. A. (2002). Los problemas de las bibliotecas escolares de la Región de Murcia en un contexto de crisis del Sistema Educativo. Anales de Documentación, $5,125-156$.

Gómez-Hernández, J. A. \& Pasadas-Ureña, C. (2007). La alfabetización informacional en bibliotecas públicas. Situación actual y propuestas para una agenda de desarrollo. Information Research, 12 (3). Retrieved from: http://eprints.rclis.org/9418/1/alfabetizacion.pdf .

Guerrero-Vives, R. M. (2012). Bases per al desenvolupament d'un lloc web per a la promoció de l'alfabetització informacional en matèries de Ciències Socials $i$ Humanes al Batxillerat de les Illes Balears (Non-published dissertation). Universitat de les Illes Balears, Spain.

Hoover, S. (2012). The case for graphic novels. Communications in Information Literacy, 5(2), 174-186.

Jiménez-Fernández, C. M. \& Cremades-García, R. (2014). Bibliotecas Escolares. Barcelona: Universitat Oberta de Catalunya.

Lindsay, E. B.; Cummings, L.; Johnson, C. M.; Scales, B. J. (2006). If you build it, will they learn? Assessing online information literacy tutorials. College \& Research Libraries, September, 329-445. 
Markey, K.; Leeder, C. \& Rieh S.Y. (2014). Designing Online Information literacy games students want to play. Lanham, Maryland: Rowman \& Littlefield.

Marquina, J. (2013). Informe Apei sobre Bibliotecas ante el siglo XXI: nuevos medios y caminos. (APEI report, 8). Oviedo, Spain: Asociación Profesional de Especialistas en Información.

Merchant, L. \& Hepworth, M. (2002). Information literacy of teachers and pupils in secondary schools. Journal of Librarianship and Information Science, 34 (2), 81-89.

Miret, I.; Baró, M.; Mañá, T.; Vellosillo, I. \& Montero, I. (2010). Bibliotecas escolares "entre comillas". Estudio de casos: buenas prácticas en la integración de la biblioteca en los centros educativos. Madrid. Fundación Germán Sánchez Ruipérez. Obtenido de: http://www.fundaciongsr.com/uploads/contenidos/doc/122-2BE\%20entre comillas.pdf

Morey-López, M.; Sureda-Negre, J.; Comas-Forgas, R. \& Mut-Amengual, B. (2010). L'alfabetització informacional entre l'alumnat universitari: Anàlisi de les competències informacionals de l'alumnat de la Universitat de les Illes Balears. Palma: Fundació lbit.

Order 2/2006, Organic Law for Education (Spain). Boletín Oficial del Estado, 106. Retrieved from: http://www.boe.es/boe/dias/2006/05/04/pdfs/A17158-17207.pdf

Order 8/2013, Organic Law for the Improvement in the Quality Education (Spain). Boletín Oficial del Estado, 295. Retrieved from: http://www.boe.es/boe/dias/2013/12/10/pdfs/BOE-A-2013-12886.pdf

Pérez de Pablos, S. (2015, 27 february). Los jóvenes no tienen las competencias digitales que está demanda el mercado laboral. El País. Retrieved from: http://tecnologia.elpais.com/tecnologia/2015/02/26/actualidad/1424967505 54898 $\underline{0 . h t m l}$

Probert, E. (2009). Information literacy skills: Teacher understandings and practice. Computers \& Education, 53, 24-33.

Somoza-Fernández, M. \& Abadal, E. (2009). Analysis of web-based tutorials created by academic libraries. The Journal of Academic Librarianship, 35 (2), 126-131.

Tejada Artigas, C. M.; Martínez-González, B; Bustamante-Rodríguez, A. T.; Cid-Rodríguez, R.; Comalat-Navarra, M; Díaz-Bergantiños, E. et al. (2013). Perfiles profesionales del Sistema Bibliotecario Español: fichas de caracterización. Madrid: Ministerio de Educación, Cultura y Deporte. Secretaría General Técnica. Subdirección General de Documentación y Publicaciones. Retrieved from: http://travesia.mcu.es/portalnb/ispui/bitstream/10421/6841/1/perfilesprofesionalesS BE.pdf 
Upson, M., \& Hall, C. M. (2013). Comic book guy in the classroom: The educational power and potential of graphic storytelling in library instruction. CULS Proceedings, 3, 2838.

Williams, P. \& Rowlands, I. (2007). Information behavior of the researcher of the future; work package II: the literature on young people and their information behavior (Nonpublished manuscript). Retrieved (2015, March, 23) from http://www.jisc.ac.uk/media/documents/programmes/reppres/ggworkpackageii.pdf

\section{Biographical notes}

Rosa Maria Guerrero-Vives has worked as a documentalist at the University of Balearic Islands in Palma, Spain, since 2008; her main research topic is Information Literacy in the Secondary Education. She has investigated how do teachers promote IL skills in their classrooms. Recently, she has trained Valencian teachers in IL skills through the online training platform of the COBDCV.

Maria Dolores Rubio-Mifsud has worked as a documentalist and as a Librarian in different public libraries and information centers in Spain, since 2006. Nowadays, one of her professional duties are related with analyzing and improving studying abilities of young users at the library. She also manages documentation, reading clubs and activities.

Mercè Morey-López is working as a Researcher and as a Professor at the University of Balearic Islands in Palma, Spain; her research career is focused on following fields: Intercultural Education, Information Literacy and Academic Integrity. Her recent publications include: the article "Plagiarism and academic performance among students of Secondary Education" in the journal Estudios sobre educación (2013) and the article entitled "Detection levels of academic plagiarism by teachers of Secondary Education: analysis according to their areas of expertise and measures taken" in the journal Revista de Estudios Pedagógicos (accepted in 2014, to be published in 2015). 


\section{Appendix I}

\section{Tutorial Evaluation Tool}

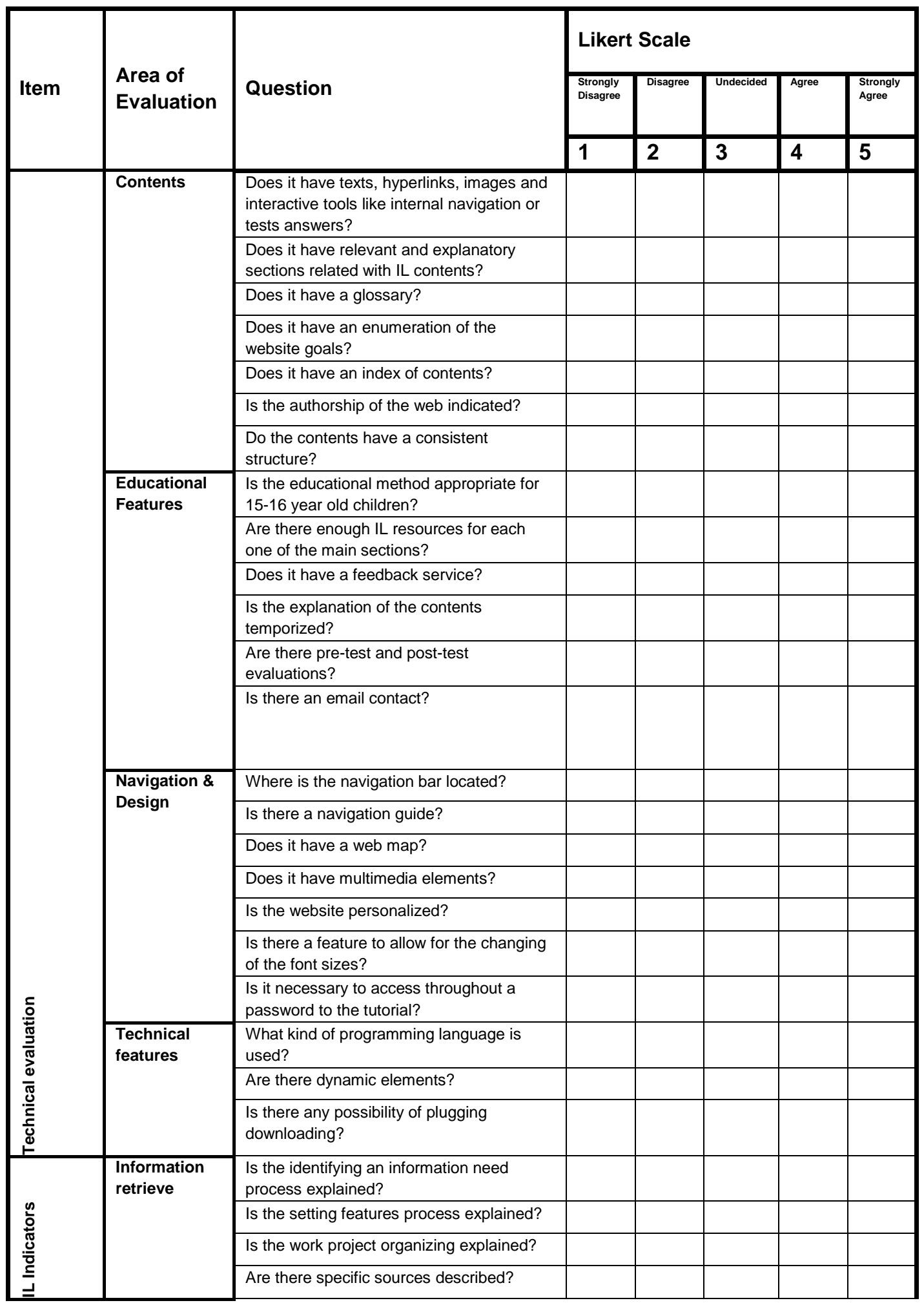




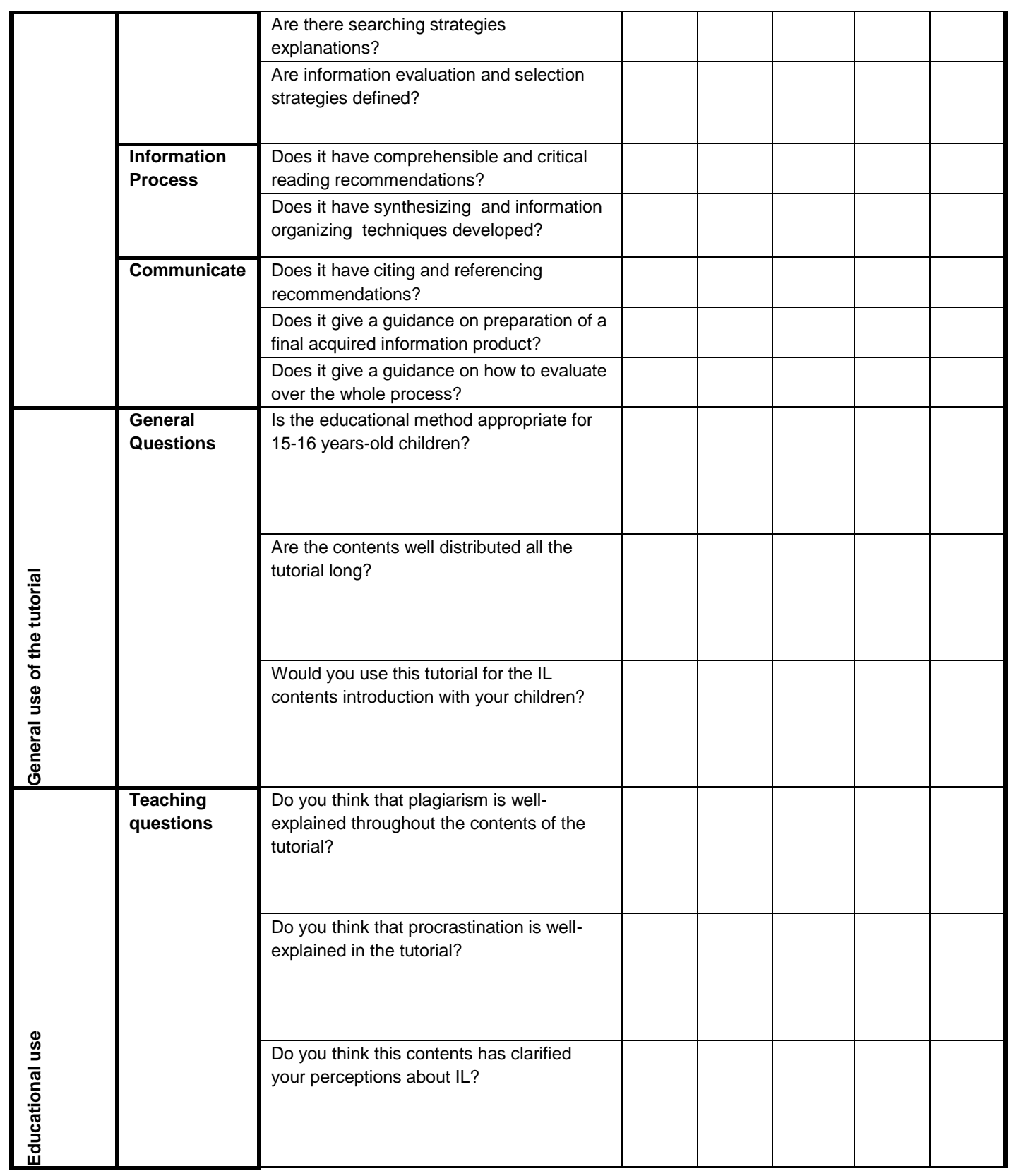

Table 2. Likert Scale questions. Source: Prepared by the authors on the basis of Somoza-Fernández and Abadal (Op. cit.) and Blasco and Durban (Op. cit.).

\section{Other qualitative questions:}

- $\quad$ Are there any elements of the IL missing from this tutorial? Which are them?

- $\quad$ Do you think students would be interested on the contents developed in this tutorial?

Why?

- Which other questions would you include in this evaluation tool?

- Which modifications would you do in this evaluation tool?

Note: Contents from this tool are not definitive. 